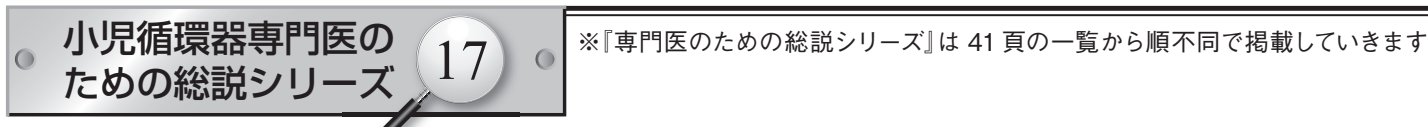

\title{
小児の心臟移植
}

福嶌 教偉
大阪大学大学院医学系研究科重症臓器不全治療学
Keywords :

children, heart transplantation, left ventricular assist support, immunosuppression, infection prevention

\section{Pediatric Heart Transplantation}

Norihide Fukushima

Department of Therapeutic for End-Stage Organ Dysfunction, Osaka University Graduate School of Medicine, Osaka, Japan

Children under 15 years of age could not donate their hearts after brain death until the Japanese Organ Transplantation Act was revised on 17 th July in 2010, because only persons who had a written consent for organ donation after brain death could donate their organs in Japan. Therefore, small children could not undergo heart transplantation (HTx) in Japan and many Japanese children had been abroad to undergo HTx. After revision of the Act, small children could be able to donate organs if their family accepted and, in fact, finally six children (one younger than 6 years, three between 10 and 14 years, and two between 15 and 17 years) donated his or her heart until the end of 2013. In this review, current status and issues of pediatric HTx in Japan and indication of pediatric HTx and management before and after HTx were described. Briefly, most indication of HTx was dilated cardiomyopathy (DCM) and restrictive cardiomyopahty in Japan and many candidates with DCM required left ventricular assist device (LVAS) for bridge to HTx in Japan. Immunosuppressive regimen was calcineurin inhibitor and mycophenolate mofetil and steroid was discontinued within 6 months in most children. Patient survival at 10 years after HTx was $100 \%$ in children transplanted in Japan and $87.6 \%$ in children transplanted abroad. Post transplant lymphoproliferative disorder and various infections were major morbidity and mortality. Non-adherence should be carefully observed while taking care of adolescent patients.

\section{要旨}

心臓移植は, すでに欧米では末期的心および呼吸不全患者の外科的治療として定着し, 外科的治療として確立しつ つある。1997 年に施行された臓器移植法は, 6 歳未満の脳死判定基準がないこと, 15 歳以下の臓器提供の意思が認め られないことから, 小児は心臓移植を受けるチャンスは極めて低く, 多くの小巟が海外で心臓移植を受けていた。 のような現状を打開するために, 改正臓器移植法が 2010 年 7 月 17 日に施行され, 脳死臓器提供者の年齢制限がなく なった。 その結果, 2013 年末までに 6 名の児童 $(6$ 歳未満 1 名, $10 \sim 16$ 歳 3 名, $15 \sim 17$ 歳 2 名) の脳死臓器提供があ り，6名の児童が国内で心臓移植を受けることができたが，身体の小さな小児や，拘束型心筋症など医学的緊急度 2 の状態で, 心臓移植を受ける必要のある小児は, いまだに海外に一縷の望みをかけて渡航しているのが現状である.

ここでは, わが国の小児心臓移植の現状を紹介するとともに, 小児心臓移植の適応, 移植後の管理について概説する.

\section{はじめに}

心臓移植は，すでに欧米では末期的心および呼吸不 全患者の外科的治療として定着し, 小児症例において も, 重症心筋症ならびに根治不可能な先天性心疾患に 対する心臓移植の臨床応用例も年々増加し, 外科的治 療として確立しつつある1．わが国でも 1999 年 2 月に
ようやく脳死体からの臓器移植が開始されたが, 小児 に関しては, 6 歳未満の脳死判定基準がないこと, 15 歳以下の臓器提供の意思が認められないことから, 心 臓移植を受けるチャンスは極めて低く, 国内で心臓移 植を受けた小児例は 5 例に過ぎず2,3)，多くの小児例が 海外で心臓移植を受けていた。

このような現状を打開するために,「茞器の移植に関 
する法律」の改正法が 2010 年 7 月 17 日に施行され,「本 人の意思が不明な場合には, 家族の書面による承諾で 脳死臓器提供が可能」となり, 臟器提供者 (ドナー)の 年齢制限がなくなったため, 2013 年末までに 6 名の児 童 (6 歳未満 1 名, $10 \sim 16$ 歳 3 名, $15 \sim 17$ 歳 2 名) の 脳死臓器提供があり, 6 名の児童が国内で心臓移植を 受けることができたが4)，身体の小さな小児や，拘束型 心筋症 $(\mathrm{RCM})$ など医学的緊急度 2 の状態で心臟移植を 受ける必要のある小児は, いまだに海外に一縷の望み をかけて渡航しているのが現状である。

\section{小児心臓移植の歴史}

小児心臓移植は, 1967 年に Kantrowitz(NY, USA) が 重症 Ebstein の生後 18 日の小児に無脳児から心臟移植 を施行したのが最初であるが5)，この症例は 6 時間で死 亡した。手術手技, 補助手段, 免疫抑制剤などの点で新 生児・幼児期の心臓移植は長い間成功例をみなかった が，1984 年にCooley(TX, USA) らが 8 力月の心内膜線 維弾性症症例に対して心臓移植に成功した6)。この頃, 米国においても小児期の脳死判定基準がなかったため に, 1985 年に Bailey (CA, USA) ら ${ }^{7)}$ は新生児の左心低形 成症候群 (HLHS) 症例に対し, ヒヒからの異種心臓移植
を行った，患児は拒絶反応ではなく，腎不全で 20 日目 に死亡したが，新生児の，しかも HLHS でも同所性心 臓移植が可能であることが明らかとなり，米国で小児 期の脳死判定基準の検討に拍車がかかる結果となり, 1986 年に基準が制定された。その後, 新生児・幼児期 を含めた小児期の心臓移植の症例数が増加し, 適応も 拡大した。また適応疾患もほとんど心筋症であったの が, 先天性心疾患の占める割合が増加していった。し かし, 小児の救急医療の進歩も相まってドナーが年々 不足しているため, 症例数は漸減してきている.

\section{小児心臓移植の適応疾患と適応基準}

心臓移植の適応疾患については, Table 1 に示す疾患 があげられる。

適応基準は本質的には，成人と差はないが，各疾患 に特徵があるので, 日本小児循環器学会移植委員会で は, 小児の心移植の適応評価のためのガイドライン Table 2 のように推奨している.

国際心肺移植学会 (ISHLT) の統計によると, 成人で は心筋症と虚血性心疾患がほぼ折半するのに対し, 小 児には年齢による違いがあり, 1 歳未満では先天性心 疾患が $54 \%$ を, 11 歳以上の小児では心筋症が $65 \%$ を

Table 1 小児心臟移植の適応疾患

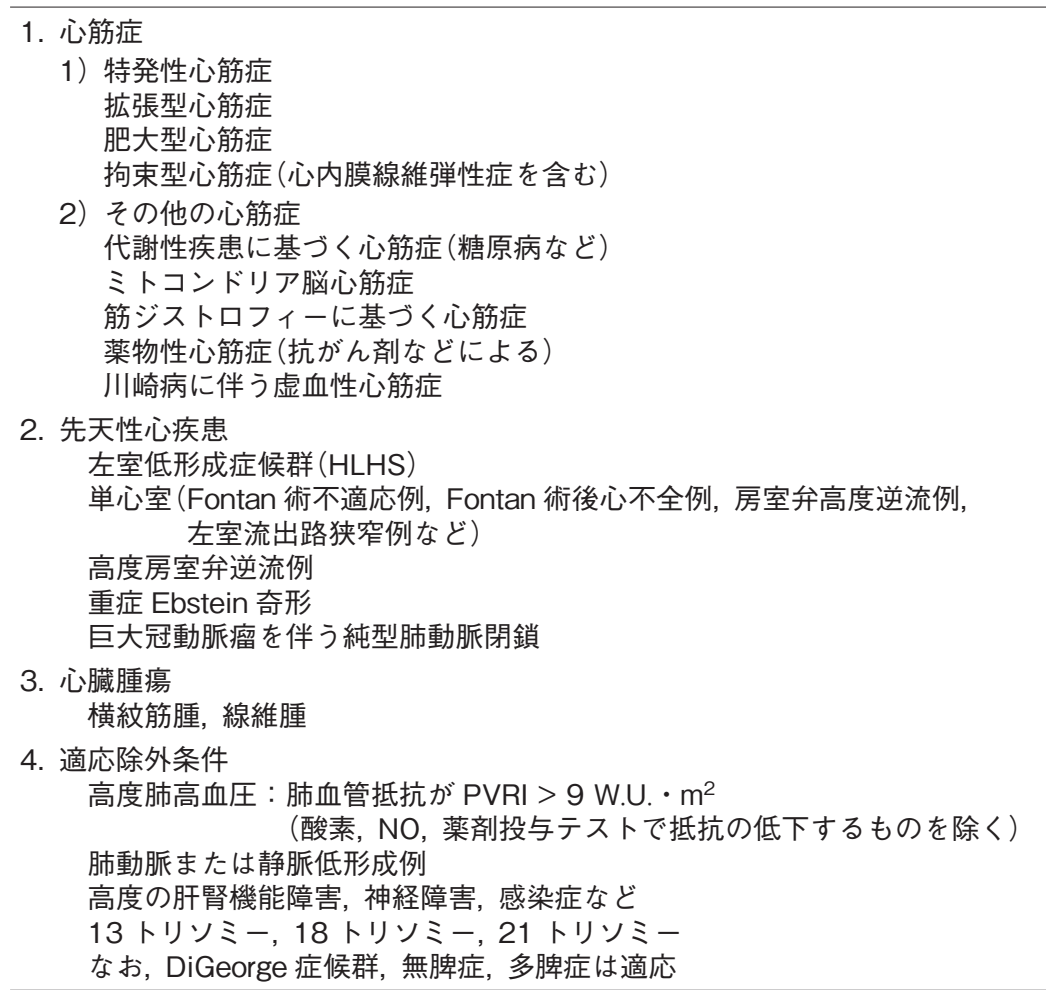


Table 2 小児心臟移植の適応判定ガイダンス

I 小児の心不全の grading

NYHA 機能分類で判定できない年齢では, 哺乳力低下, 体重増加不良, 発育障害, 易感染性 (特に繰り返す呼吸器感染), 多呼 吸・努力呼吸なども心不全の grading として考慮する.

II 各疾患ごとの判定ガイダンス

1. 拡張型心筋症・拡張相肥大型心筋症：薬剂治療に反応しない心不全症状を認めれば適応と考えられるが，十分な内科的治 療を行った上で, 以下の所見を認める拡張型心筋症・拡張相肥大型心筋症は予後不良であり心臓移植の適応と考えられる.

( $\beta$ 遮断薬, ACE 阻害薬の有効性にはまだ議論があり, 必ずしもこれらの薬剤の使用効果を必須の条件としなくてよい)

1) LVEDP $>25 \mathrm{mmHg}$

2) LVEF $<30 \%$

3)治療抵抗性の致死性心室性不整脈

4) Near-death experience

5) 2 歳以降の発症

6) カテコラミンの使用

2. 拘束型心筋症：内科的治療を十分行っても以下の所見を認める拘束型心筋症は予後不良であり, 心臟移植の適応と考えら れる.

1)肺うっ血の所見

2) NYHA3 度以上

3) 心房拡大 (LA/Ao > 1.5), 心胸郭比 > 55\%

4)肝うっ血の所見

5) 低年齢の発症 (とくに 2 歳以前)

3. 左室低形成症候群：以下の条件に当てはまる場合.

1) 高度三尖弁閉鎖不全

2) 低右室駆出率 (RVEF < 30\%)

3) 冠不全(高度大動脈低形成など)

4) 総肺静脈還流異常合併

4. 単心室型先天性心疾患

- Fontan 型手術前

1) 軽度肺血管抵抗上昇 $\left(P V R I<9\right.$ W.U. $\left.\cdot \mathrm{m}^{2}\right)$

2) 低体心室駆出率 (SVEF $<30 \%)$

3) 高度房室弁逆流

4) カテコラミンの持続投与が必要な場合

5)薬剂抵抗性の致死的不整脈

- Fontan 型手術後

1)薬剤抵抗性の心不全

2) 高度房室弁逆流

3) コントロールできない蛋白漏出性胃腸症

4) チアノーゼの著明な肺動静脈瘻

5) 高度左室流出路狭窄

6) 治療抵抗性の致死的不整脈

5. その他の先天性心疾患 : 重症 Ebstein 奇形, 冠動脈異常をともなう純型肺動脈閉鎖

6. 心臟腫瘍：横紋筋腫, 線維腫などが心臓に広範囲にあり, 心臓以外に腫瘍がない場合

III 適応除外条件

高度の肝腎機能障害, 高度精神神経障害, 全身性感染症, 高肺血管抵抗 $\left(P V R I>9 \mathrm{~W} . U . \cdot \mathrm{m}^{2}\right)$, 高度肺動脈低形成・肺静脈狭 窄など

占める1) (Fig. 1).

1. 心筋症

成人同様の特発性拡張型心筋症〔拡張型 (DCM), 肥 大型 (HCM), RCM]に加え, 代謝性疾患に基づく心筋 症(糖原病など), ミトコンドリア脳筋症, 筋ジストロ フィーに基づく心筋症, 薬物性心筋症(抗癌剂などによ る)，川崎病に伴う虚血性心筋症などがある，肥大型心 筋症の拡張相〔dilated phase of $\mathrm{HCM}(\mathrm{dHCM})]$ で適応と なるものは成人に比較すると少ない。これに対し，心 内膜線維弾性症を含む RCM の頻度は成人に比較して 高い. 肺高血圧や肝硬変に進行するまでに, 心臓移植 の可否を判定することが重要である.

DCM では 2 歳以上の発症, RCM で 2 歳未満の発症 が予後不良のため, 心臟移植の適応となる。近年, DCM の場合, $\beta$ 遮断剂・ACE 阻害剂治療の多施設にわたる 検討が始まり, 有効例も報告8)されてきているが, 成人 


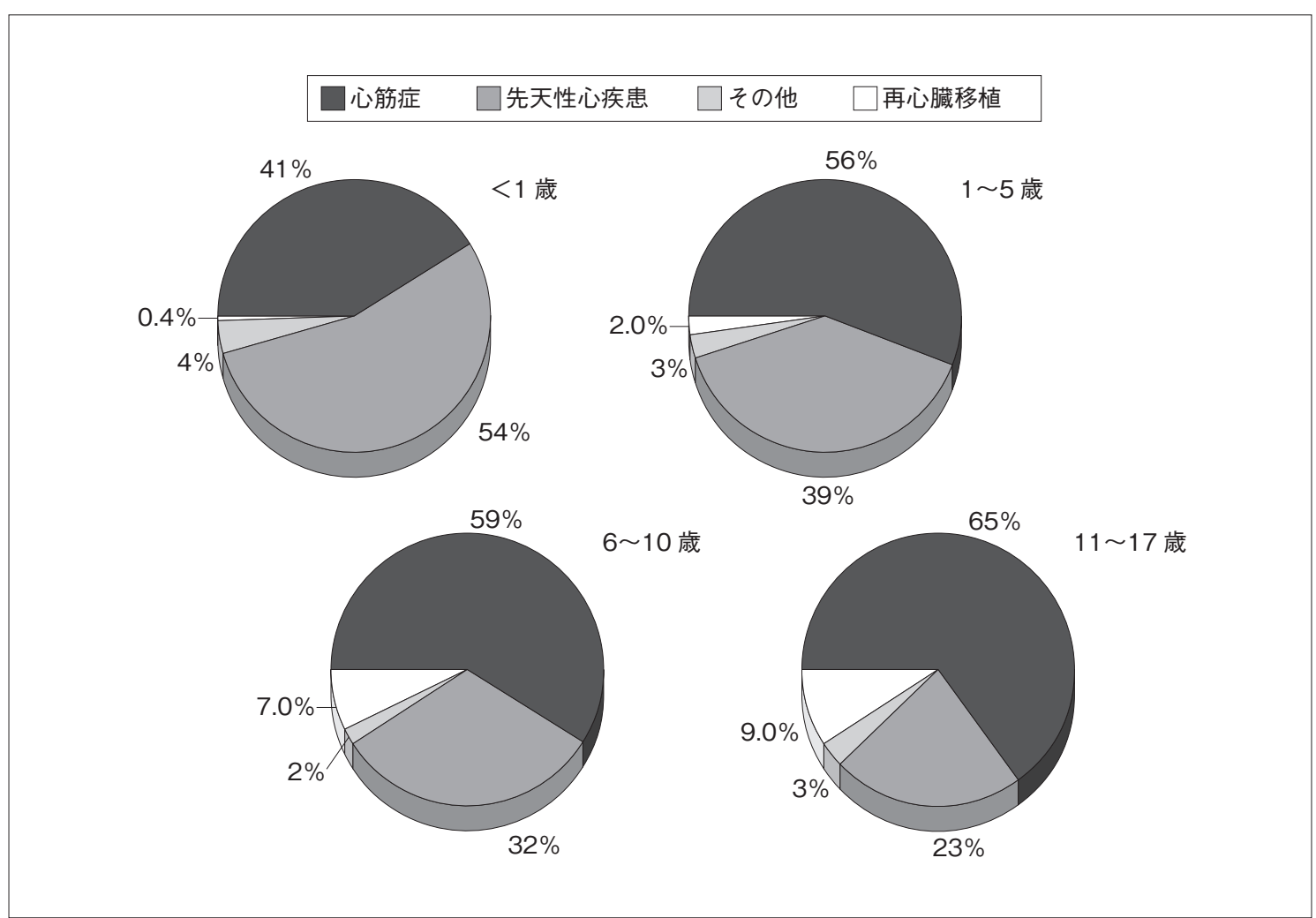

Fig. 1 小児心臓移植の適応疾患 (年齢別) (2006.6 2012)

国際心肺移植学会(ISHLT) 統計による

に比較して無効例が多い傾向にある。

\section{2. 先天性心疾患}

HLHS が最も代表的な適応疾患である。これに加え て, 外科的に修復不可能な先天性心疾患が適応となる。 代表的なものとして, 新生児・乳児期には重症 Ebstein 奇形, 巨大冠動脈瘻を伴う純型肺動脈閉鎖などがあげ られるが，それより大きな小児期には，単心室 (Fontan 術不適応例, Fontan 術後心不全例, 房室并高度逆流例, 左室流出路狭窄例など), 高度共通房室弁逆流例などが 適応となる。この場合, 肺血管抵抗係数(PVRI) が 9 W.U. $\cdot \mathrm{m}^{2}$ 以上の高度肺高血圧症例 (酸素, $\mathrm{NO}$, 薬剂投 与テストで抵抗の低下するものを除く)，肺動脈または 静脈低形成例は適応とならない。ただし，肺血管抵抗 の高い場合 $\left(9 \mathrm{~W} . \mathrm{U} \cdot \cdot \mathrm{m}^{2}\right.$ 以上)でも，虚血時間が短く， ドナー体重が大きいものを用いれば移植後の肺高血圧 による死亡がないと報告されており9,10)，移植前の評価 法が検討されている。

\section{3. 心臟腫瘍}

横紋筋腫，線維腫などがある.

\section{4. 適応除外条件}

高度の肝腎機能障害, 神経障害, 感染症などは, 成人 と同様禁忌となる。13や 18 トリソミーなど，心疾患以 外で生命予後が規定されている場合には適応とならな い. 21 トリソミーは, 免疫抑制剂の副作用としてのリ ンパ系増殖性腫瘍に罹患する率が高いので適応となら ない。これまでの経験から, DiGeorge 症候群, 無脾症, 多脾症は，移植後の感染症・拒絶反応の頻度が，それ 以外の症例と差がないので適応とされている。

\section{移植後の管理}

1. 免疫抑制療法

小児においても、シクロスポリン $\operatorname{CsA}$ 、ネオーラ 
ル $\left.{ }^{\mathrm{TM}}\right)$ またはタクロリムス ( $\mathrm{TAC}$, プログラフ), プレド ニゾロン $\left(\mathrm{PRD}, フ^{\circ} レ\right.$ ドニン $\left.{ }^{\mathrm{TM}}\right)$, ミコフェノール酸モ フェティル $\left(\mathrm{MMF}\right.$, セルセプト $\left.{ }^{\mathrm{iM}}\right)$ の三者併用療法が移 植後早期の基本的免疫抑制療法である ${ }^{8}$. Table 3 に免 疫抑制薬の投与の具体例を示す.

移植前に腎機能障害のある例, 免疫学的なハイリス ク症例 (panel reactive antibody 高值, クロスマッチ陽性 等)では抗インターロイキン 2 受容体抗体 (シムレク 卜 $^{\mathrm{TM}}$ )または抗胸腺細胞抗体製剤(ATG：サイモグロブ リン ${ }^{\mathrm{TM}}$ )を用いる場合がある(なお，抗体製剤は，2013 年 末の段階では保険収載されていない)。成長・感染症な どを考慮して, 遠隔期には可能な限り PRD の中止を考 慮する(できれば 6 カ月以内)。また, 液性拒絶反応を 発症した例, 遠隔期に移植後リンパ増殖性疾患 (PTLD) や中等度以上の腎機能障害を来した例では, エベロリ ムス $\left(\mathrm{EVL}\right.$, サーティカン $\left.{ }^{\mathrm{TM}}\right)$ の使用を考慮する。それぞ れの免疫抑制薬には注意すべき副作用があり（Table 4), なかでも腎機能障害や思春期の总薬に結びつく容 姿に関連する副作用には留意する必要がある。

\section{2. 拒絶反応の診断と治療}

成人では今な抧心筋生検が拒絶反応の golden standard であるが, 小児例では心筋生検の合併症を避けるため に, non invasive な診断法を重要視し，それでも診断の つかない症例に心筋生検を施行している施設が多い. non invasive な検査法として, 心臟超音波検査が最も重 要視され ${ }^{9)}$, 左室壁厚, 拡張期時間, 駆出率, 僧帽弁逆流, 心囊液貯留などをスコア化し, 移植後経日的に測定し てスコアに変化があれば拒絶反応と診断する方法を とっており，臨床的には非常に有用である(Table 5).

移植後にステロイドを多く用いると成長障害などの 問題があり，極力使用量を少なくするか，早期に中止す る. 思春期の患児では, 副作用の多毛, 肥満などを気に して薬を服用しない場合があり，十分な注意を要する.

拒絶反応の治療法自体はあまり成人と差はなく, ステ ロイドのパルス療法を第一選択とし，必要に応じて抗 胸腺細胞抗体製剂を用いる。臟超音波検查で拒絶反 応を診断した場合には, 治療の効果も超音波検査で判 定する。一般的な治療で改善が認められない場合には, 心筋生検を行って, 診断する. 難治性の場合, ウイルス 性心筋炎を合併する場合があるので, 生検標本を用い て予想されるウイルスの PCR 検査を行うことがある.

難治性の症例では, 血漿交換, 全身リンパ節放射線 照射を行う.

\section{3. 感染症の診断と治療}

小児の場合, 特に新生児・乳児例では, 移植前に罹 患してない感染症が多いため, 成人に比して感染症に 罹患しやすい. 特にウイルス感染症に罹患しやすいの で，その予防に注意を要する。

日常生活の管理が重要で, マスク・手洗い・うがい の励行, 生もの(さしみ, 納豆, 生卵など)の摂食禁止, 動物の世話当番禁止などを行う (Table 6). 患児がなる ベく普通の生活ができるように, 幼稚園や学校の教諭 などと十分な話し合いをすることが重要である.

成人に比して Ebstein-Barr ウイルスに罹患しやすく, しばしばPTLDに罹患する。

心臟移植後は免疫抑制剂を投与するため, 生ワクチ ンの使用を避ける必要がある。したがって, 可能なら ば生ワクチンの必要な感染症に対しては, 移植前に投 与することが望ましい。

\section{4. 精神的支援}

心臓移植を受けた患児の多くは, 自分で心臓移植を 受けるかどうか決めていないことが多い.また，移植 後服用する薬剤には, 肥満, 多毛, ニキビ, 歯肉腫脹な ど(Table 4), 思春期の患児にとって好ましくない副作 用も多い.また，思春期は，自分の生きている意味など を考える時期であり, 海外渡航移植では募金をはじめ 多くの支援を周囲から受けていたり，ドナー・その家 族に対する自責の念を持ったりする場合には，精神的 な暮藤は普通の小児に比してとても大きいのが特徴で ある。このような要因が怠薬の原因となり, 移植心が 廃絶,つまり死に至ることも決して少なくない.した がって, 前記の医学的管理に加えて, 細やかな精神的 支援が重要であり, child life specialst, 臨床心理士など 多職種での治療体系を構築することが重要である.

\section{世界における小児心臓移植}

\section{1. 症例数}

1980 年始めのシクロスポリンの導入に伴い, 小児心 臓移植症例も増加したが, ドナー不足のために 1990 年 頃からプラトーとなり，現在では年間約 $500 \sim 550$ 例 施行されている1)(Fig. 2). 
Table 3 小児免疫抑制療法 三剂併用療法の実際

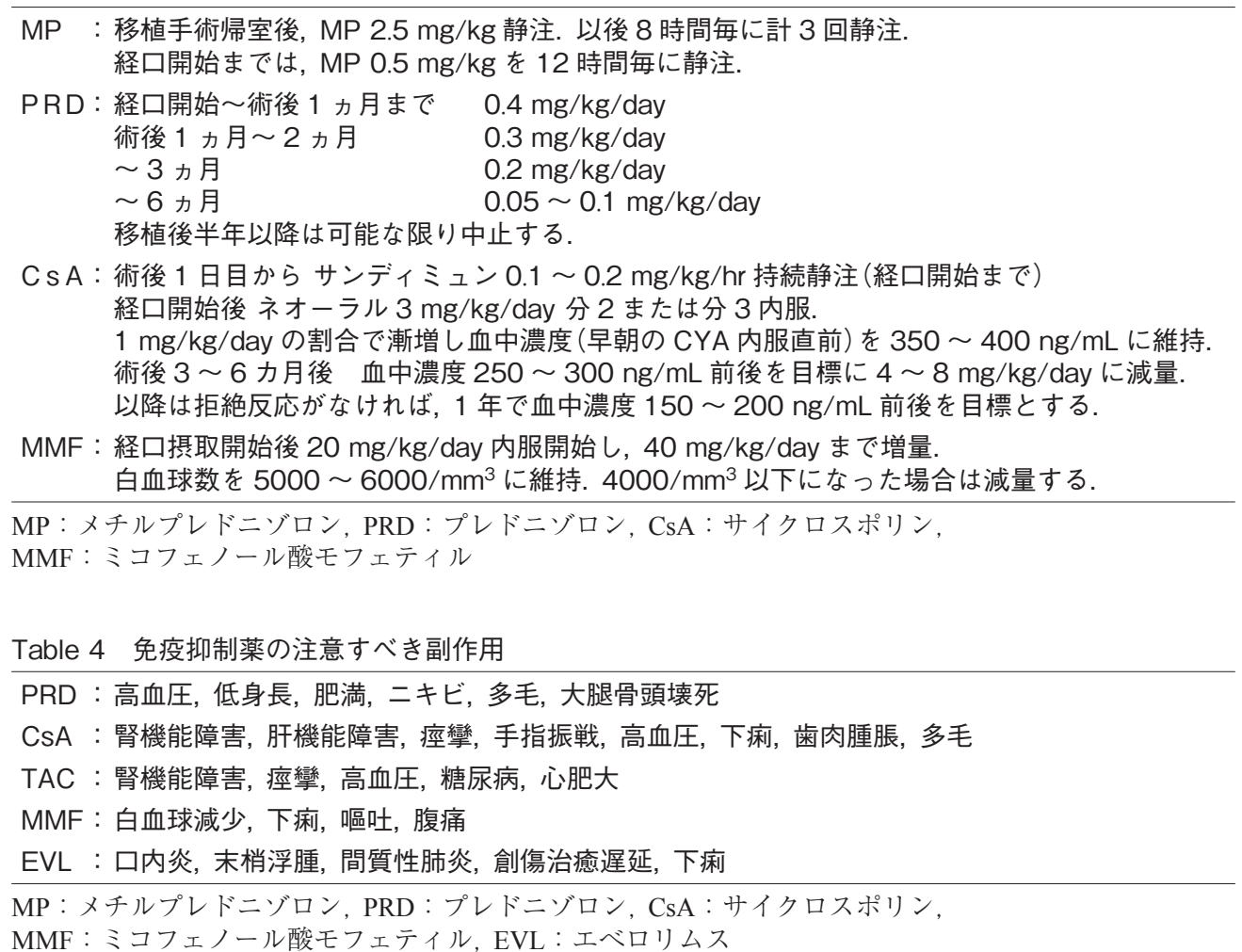

Table 5 心エコーによる拒絶反応の指標の閾值とスコア

\begin{tabular}{|c|c|c|c|c|}
\hline \multirow{2}{*}{ 指標 } & \multicolumn{2}{|c|}{ 新生児 } & \multicolumn{2}{|c|}{ 小児 } \\
\hline & 閾値 & スコア & 閾値 & スコア \\
\hline 左室 FS (fractional shortening) & $<29 \%$ & 拒絶 & $<29 \%$ & 拒絶 \\
\hline 心室中隔 thickening 変化率 & $<25 \%$ & 1 & $<25 \%$ & 1 \\
\hline 左室後壁 thickening 変化率 & $<60 \%$ & 2 & $<60 \%$ & 2 \\
\hline 左室充満速度 & $<40 \mathrm{~mm} / \mathrm{sec}$ & 1 & $<60 \mathrm{~mm} / \mathrm{sec}$ & 1 \\
\hline 左室後壁 thinning/ 壁厚の最大速度 & $<8 / \mathrm{sec}$ & 1 & $<11 / \mathrm{sec}$ & 2 \\
\hline 左室拡張末期容積指数変化率 & $<30 \%$ & 1 & $<60 \%$ & 2 \\
\hline 左室重量指数 & $>130 \%$ & 1 & $>130 \%$ & 1 \\
\hline 左室拡張末期容積 / 重量 & $<0.35$ & 1 & $<0.4$ & 1 \\
\hline 僧帽弁または三尖弁逆流 & $>$ mild & 1 & $>$ mild & 1 \\
\hline
\end{tabular}

スコア合計による評価

0 : 正常, 1〜3: ほぼ正常, 4〜6: ISHLT grade 3 以上疑い, $7 \sim$ : ISHLT grade 3 以上

\section{2. 小児心臓移植後の予後とQOL}

移植後の成績は, 免疫抑制剂の改良, 移植手技・補 助手段の改良に伴い向上し, 1982 1989 年では 3 年 生存率が $63.2 \%$ であったのが, 2005 ～ 2011 年では 83.2\%になった1) (Fig. 3).

年少児は先天性疾患など複雑な修復を伴ったり, 臓 器が未熟であったり，高肺血管抵抗を伴っていることが
多いため, 移植後早期の死亡率は年長児に比較して高 い(30日以内の死亡率は, 1 歳未満 $14.5 \%, 1 \sim 5$ 歳 9.5\%, $6 \sim 10$ 歳 $8.6 \%, 11 \sim 17$ 歳症例 7.4\%). しかし逆に, 年 少児の拒絶反応(特に移植後冠動脈硬化症： posttransplant coronary artery disease : TxCAD)の頻度 · 重症 度が低いので, 移植後 1 年を過ざると年長览の死亡率が 相対的に増加し，遠隔期には差がなくなる，具体的には 1 歳未満, $1 \sim 5$ 歳, $6 \sim 10$ 歳, $10 \sim 17$ 歳の 1 年生存率 
Table 6 食品に関する注意事項

1) 避けるべき食品 生の肉・魚(刺身)・にぎり寿司

グレープフルーツジュース

皮の剥けない果物 (イチゴ, ブドウなど)

絞りたての牛乳など非加熱の乳製品

ドライフルーツ

発酵食品 (生味噌類・納豆)

カビを含んでいるチーズ

生の木の実

減塩の梅干し

自宅で漬けた漬け物（梅干など）

調理後 2 時間以上たった食品

期限切れの全ての食品

煮沸していない漢方薬

2) 注意事項

缶詰は缶の形が変化し表面に傷がないか確かめ, 水洗いをしてから開封し当日使い切る.

パック食品(牛乳, ジュース, プリン, ゼリー) は無菌充填・加熱殺菌表示のあるもの.

果物は新鮮で傷のない物を選び, 基本的には皮をむける物に限る. 流水で十分に洗浄.

飲料用の缶・ビン・ペットボトルは開封後 24 時間以内に処分し, 飲み残しは飲まない.

ミネラルウォーターは製品の滅菌行程がはっきりしないものは避ける.

アイスクリーム・シャーベット・氷は個別密閉包装されているものに限る.

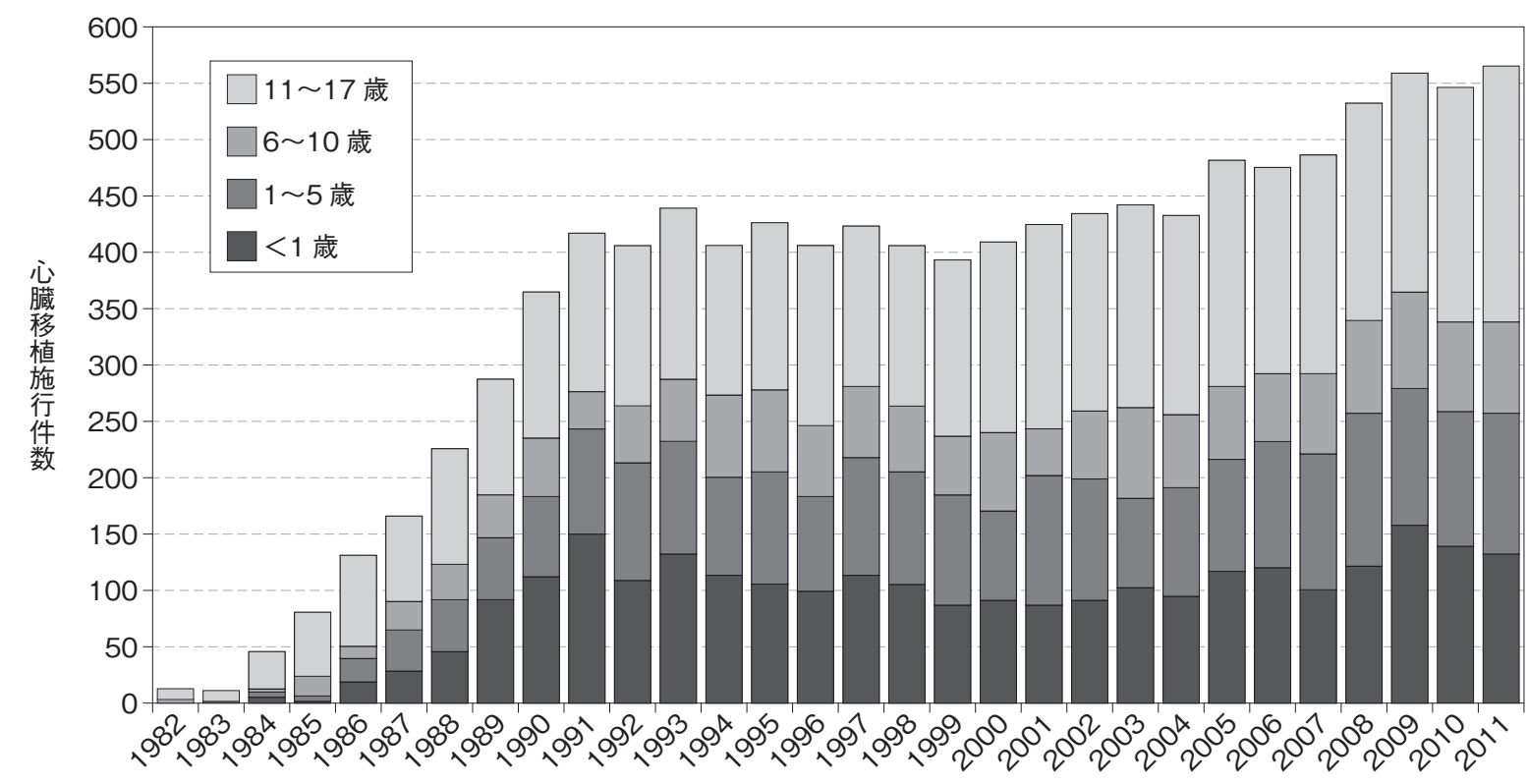

Fig. 2 世界の小児心臓移植の推移(年齢別)

国際心肺移植学会(ISHLT)統計による

はおのおの $76.2 \%, 82.4 \%, 86.9 \%, 86.4 \%, 5$ 年生存率は おのおの $67.0 \%, 72.3 \%, 77.0 \%, 71.5 \%$ であるが, 15 年 生存率はおの㧍の $55.5 \%, 54.7 \%, 48.7 \%, 45.1 \%, 20$ 年 生存率はおのおの $49.3 \%, 41.8 \%, 35.4 \%, 37.1 \%$ で, 年 少児ほうが年長児より累積生存率が高くなる1) (Fig. 4).

1 年以上生存した例でその後の死亡率をみるとその
傾向が明らかで, 先天性心疾患でその傾向が強いが, 心筋症ではその傾向はみられない。死因としては，移 植後 30 日以内には細菌性感染症, 移植心不全 (一次性. 肺高血圧などによる二次性とも) が多いが，3 年以内ま では急性拒絶反応が多い. 移植後 1 年を過ぎると $\mathrm{TxCAD}$ が増加し, 3 年以上になると死因の $40 \%$ 近い 1$)$. 


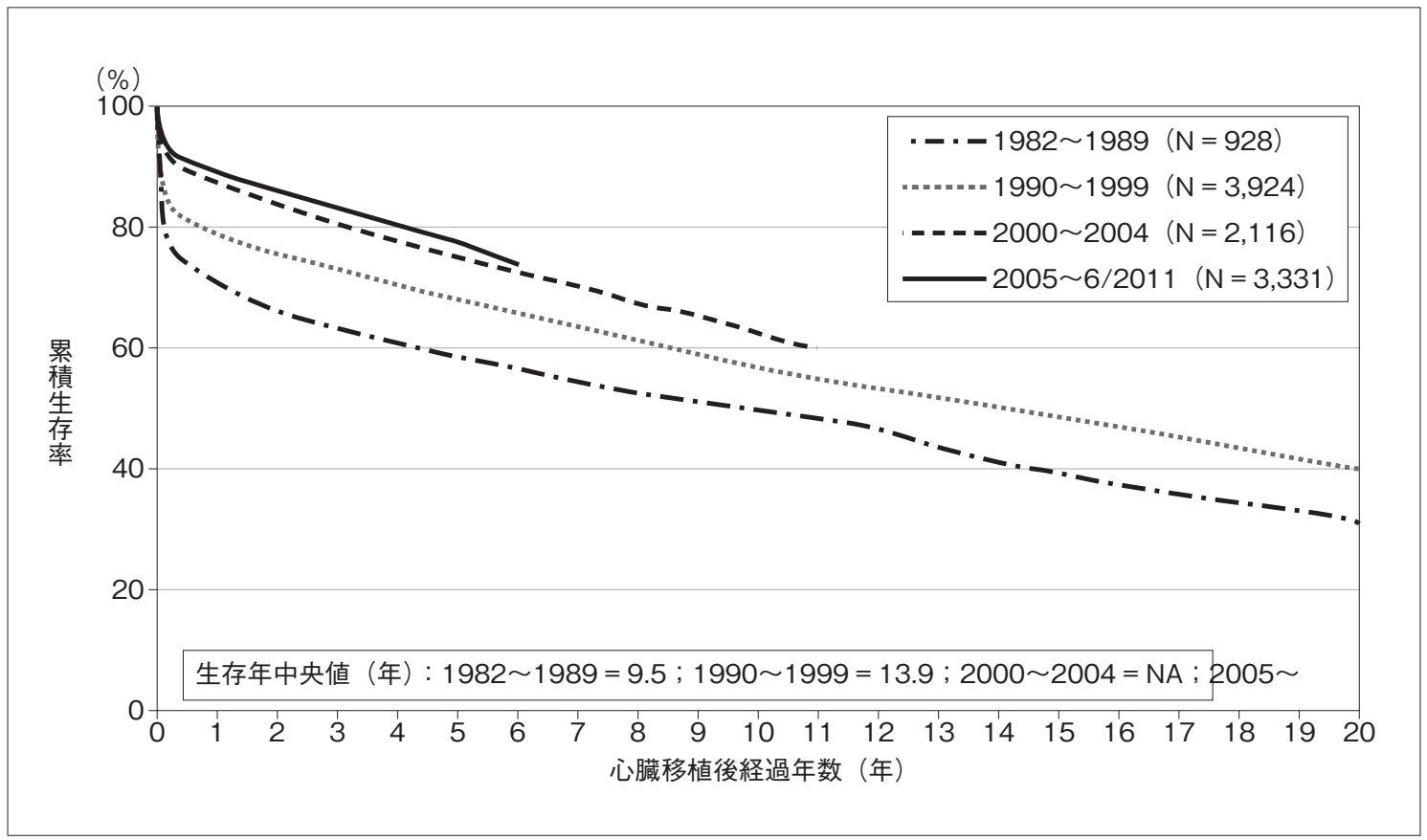

Fig. 3 世界の小児心臓移植後の累積生存率 (年代別) (1982.1 2011.6)

国際心肺移植学会(ISHLT) 統計による

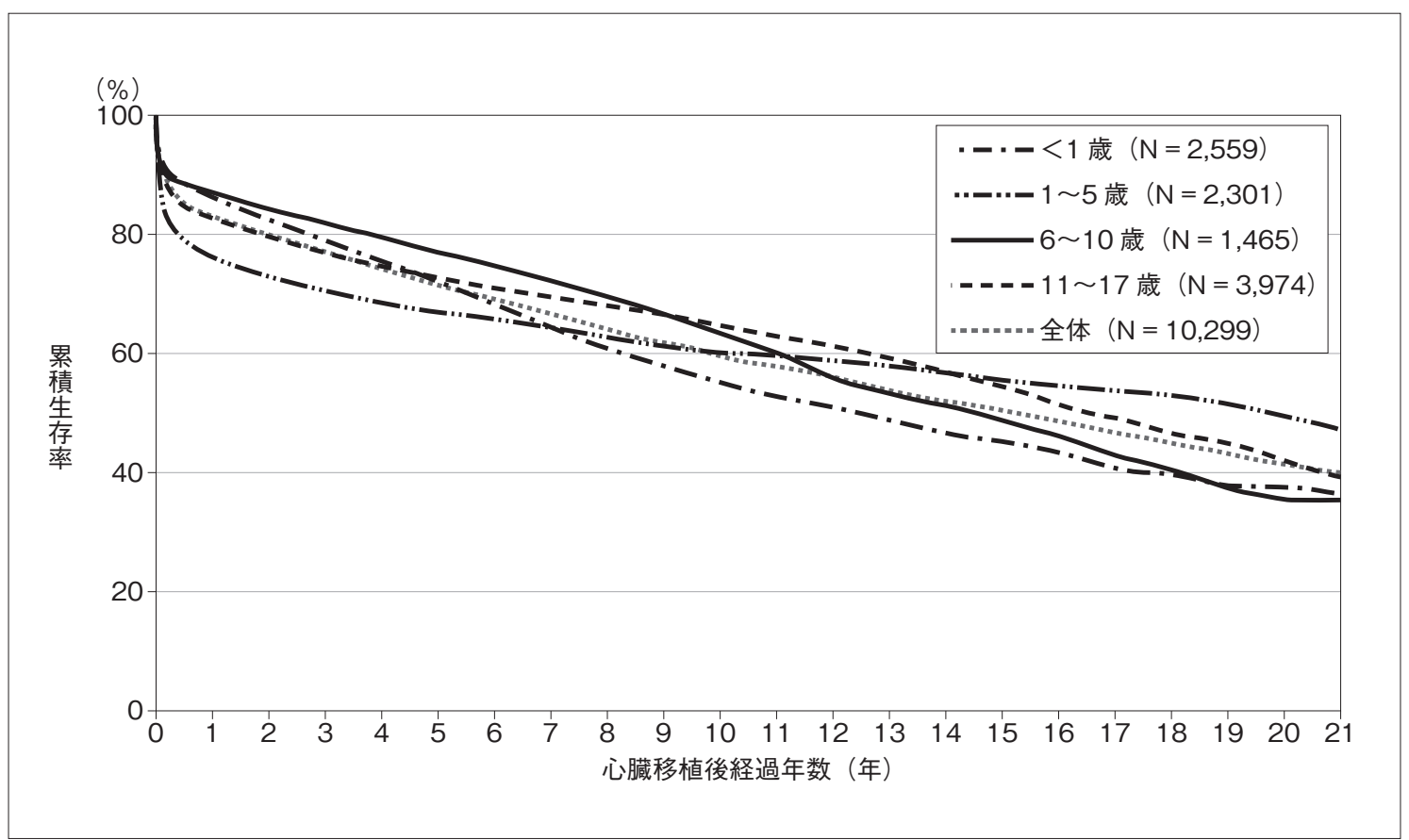

Fig. 4 世界の小児心臓移植後の累積生存率 (年齢別) (1982.1 2011.6)

国際心肺移植学会(ISHLT)統計による

移植後の日常生活については, $1,2,3$ 年後に活動制 限のない小児がおのおの $92.8 \%, 94.8 \%, 95.0 \% に$ 対し， 完全介護を要する小児が各々 $1.1 \%, 0.6 \%, 0.1 \%$ であり， QOL も向上する. 移植後, 治療のために入院する率は,
移植後 1 年以内は $50 \%$ 近いが, 年々減少し, 5 年経過 すると $27 \%$ に留まっている, なお, 入院の原因は, 拒 絶反応 $+/$ - 感染症で約 70\%を占めている1). 


\section{日本人小児の心臟移植の実態}

1. わが国における小児心臟移植適応症例の全国調査

日本小児循環器学会移植委員会の全国調査 ${ }^{10)}$ による と,わが国で心臓移植を必要とする小児は毎年 50 例程 度 (10 歳未満は 30 例程度)であり, DCM, RCM が多い。 また西川ら関東心筋疾患研究会の調査結果では11), 適 応とされてからの 1 年生存率は $32.5 \%$, 死亡までの平 均生存期間は 7.5 カ月であった。このことから, 成人の 心臓移植適応例に比べ, 心不全悪化の速度が速いため, その点を考慮した対応が必要である，さらに，心不全 悪化の際ある程度の体重がないと (20kg 以上)成人のよ うな循環補助装置が適用できないことも小児における 心臟移植待機の困難性を増す要因と考えられる。

\section{2. 日本臟器移植ネットワークに心臓移植登録され た小児例}

1997 年 3 月 1 日〜 2013 年 12 月末までに日本循環器 学会で心臟移植の適応が検討された症例1,023 例中, 15 歳未満の症例は 132 例で, 120 例が心臟移植の適応と判 定された。 その内, 日本臟器移植ネットワークに登録さ れた症例は 36 例に過ぎず，その内 7 例が国内で移植を 受け, 9 例が待機中に死亡し, 15 例が待機中である $(5$ 例は登録を取消し, 海外渡航)。一方, 国内で登録後海 外渡航した症例を含め, 53 例が海外渡航移植している.

\section{3. 小児海外渡航心臟移植症例}

著者らが, 日本小监循環器学会移植委員会, 海外渡 航移植研究班, トリオジャパン, 各種インターネット 情報等の協力により，調べた限り $1988 ２ 013$ 年 12 月 末までに 98 例の小児 (18 歳未満) が海外で心臟移植を 受けた。年次推移を図に示すが, 臟器移植法施行後に かえって増加し, 自国内の臟器提供を推進することを 詠ったイスタンブール宣言が 2008 年 5 月に出された 以後減少したが，改正法施行後も身体の小さな小児の 海外渡航移植は年 4 名程度で持続している (Fig. 5).

海外で心臓移植を受けた 98 例の渡航先をみると, ア メリカ 81 例, ドイツ 8 例, 英国 4 例, カナダ 4 例, フラ ンス 1 例であり, 改正法施行後はほとんどがアメリカ で，カナダでの移植がわずかに加わるのみになってい る. 移植時の年齢は $0 \sim 18$ 歳 (平均 8.3 歳), 男児 49 例, 女児 49 例で, 適応疾患の内訳は DCM64 例 (冠動脈形成 異常 1 例含む), RCM23 例, 虚血性心筋症 1 例, 先天性
心疾患術後 8 例, 川崎病後 2 例であった. 移植待機期間 は $0 \sim 487$ 日 (平均 55 日, 100 日以上は 5 人のみ)であり, 国内移植 16 例の待機期間が $182 \sim 2,026$ 日 (平均 747 日) であったのに比し平均待機期間は短い。渡航時に左心 補助人工心臟 $(\mathrm{LVAS})$ を装着していた例は, $11 〜 17$ 歳 で 38 例中 18 例 (47\%), 10 歳以下では 60 例中 6 例 (10\%) で, 1 歳女児の 1 例 (Berlin Heart) を除き,すべて成人用・ 体外型のニプロ LVAS であった，渡航後から移植まで に新たにLVAS 装着となった例が 10 歳以下で 2 例, 11 〜 17 歳 1 例あり, さらに 10 歳未満では 5 例が $\mathrm{ECMO}$ 装着に至っている。したがって小児であっても，98 例 中 41 例 (42\%)が移植時に循環補助装置を装着していた ことになる。

移植心不全で 1 例が両心補助人工心臟装着 (BVAD), 4 例が $\mathrm{ECMO}$ を装着され, BVAD 例は多臓器不全で死 亡した. ECMO の 4 例のうち, 2 例は離脱し生存中, 1 例は多臟器不全で死亡したが, 1 例は 3 日後に再移植 を施行し, 生存中である。

再移植は先に述べた ECMO 離脱困難例と体外循環か ら離脱できたが心不全の遺残した 1 例の 2 例に施行さ れた。

移植後の死亡は 98 例中 13 例 (13.3\%) で, 急性期死 亡の原因は, 急性拒絶反応 3 例, 多臟器不全 2 例, 出血 1 例であり，慢性期死亡の原因は, PTLD 2 例, PTLD 治 療後の血球領食症候群 1 例, TxCAD 2 例 ( 1 例は PTLD と重複), 脳血管障害 2 例, 心筋炎 1 例であった

\section{4. 国内での小児心臟移植症例}

これまで, 登録時点で 18 歳未満だった児童への心臓 移植(成人ドナー 10 例) が国内で 16 例行われた。 DCM14 例, RCM 1 例, dHCM 1 例で, 男児 11 例であった. 13 例で移植前にニプロ LVAS が装着され，2 例がカテ コラミン投与, 1 例が医学的緊急度 2 (入院待機)であっ た. 16 例の待機期間は $182 \sim 2,026$ 日（平均 747 日), LVAS 装着期間は237〜1,165 日（平均 740 日）であった。 1 例が移植後 11 年目に腎不全で死亡したが, 他の 15 例は生存中である。

改正臟器移植法が施行されるに当たり, 18 歳未満の ドナーからの心臓が 18 歳未満で登録されたレシピエ ントに優先されるルールができた，その結果，児童か らの提供を受けたレシピエントの待機期間は当初 1 年 以内に短縮されたが，5例目からは 800 日以上となり， 児童からの提供でも待機期間が長くなっている(表7). 
(人)

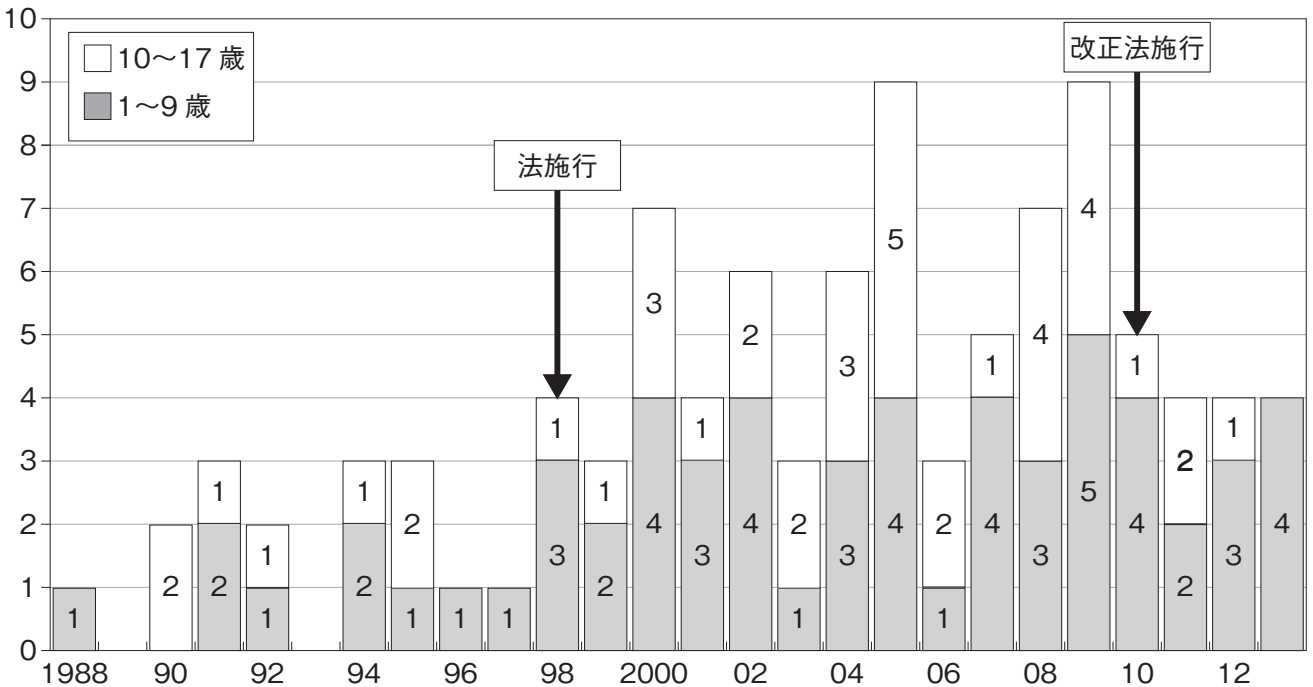

Fig. 5 小児海外渡航心臟移植実施数の推移 (1988.1.1 2013.12.31, N = 98)

\section{5. 日本人小児の心臓移植の成績}

国内の小児の心臓移植の移植後の $1,3,5$ お よび 10 年累積生存率は, すべて $100 \%$ （ただし，最長例がその 後 11 年目に腎不全で死亡), 一方, 海外渡航移植の小 児の心臓移植の移植後の $1,3,5,10$ および 20 年累積 生存率 $94.9 \%, 92.6 \%, 87.6 \%, 81.3 \%$ および $81.3 \%$ であ り，Fig. 3 に示した欧米の成績より良好である(Fig. 6). これは世界有数の小児心臟移植施設で移植を受けたこ と, 州国後紹介医がきめの細かい管理をしていること, ならびに家族が注意深く患児を見守っているからであ ろう。

なお, 臟器移植法施行後 13 年間に海外渡航移植を希 望し, 医療施設で検討された症例は 114 例にのぼり, 73 例が移植に至ったが，24 例が渡航準備中に，12 例が 渡航後待機中に死亡 (全例が渡航希望後 1 年以内に死 亡)している。

\section{臓器移植法改正後の小児心臓移植の問題点と今後の展望}

全国調査から見ても, 少なくとも年間 50 例近くの小 児が心臓移植を必要としているのに対し，法制定後の 10 年あまりに国内で 16 例，海外で 98 例の心臟移植が 実施されたに過ぎず，移植例の予後と QOL が世界の成
績と遜色ない結果と考えると，わが国でも早期に増加 することが期待される。

海外渡航移植についてはレシピエントならびに家族 の経済的・精神的支援がよく問題となっているが,「日 本での小児の脳死は否認し, 欧米の小児の脳死を肯定 する」という，倫理的に重大な問題を抱えていること を忘れてはならない，また，日本の子供が心臓移植を 受けた分だけ，その国の子供が心臓移植を受けられな いで亡くなっている可能性があることも重要であり, 国際摩擦の原因ともなりえる課題である。いずれにし てもすでに法の見直しの時期に入っており，わが国の 小児心臟移植の必要性を考慮して早期に検討すべきで あろう. 法改正により小児ドナーからの臓器提供が可 能にあったが，わが国における心臓の提供は極めて少 なく, 待機期間は極めて長くなるため, 小さな小児で も応用できるような補助人工心臓の開発が必要であ る. 人工臟器は小児の成長に対応できないので, 移植 後の成長が期待できる異種移植についても臨床応用を 目指した研究12)が発展することが望まれる.

以上，さらなる医療技術の発展を目指して研鑽を詰 むことは当然であるが, 当面の問題として, 法が見直 され，すこしでも多くの小児がわが国で心臓移植を受 けられる社会がくる日が期待してこの項を終える。 
Table 7 我が国における児童 (18 歳未満) からの脳死臓器提供

\begin{tabular}{|c|c|c|c|c|c|c|}
\hline & 2011.4 .13 & 2011.9 .4 & 2012.6 .15 & 2013.5 .16 & 2013.8 .10 & 2013.12 .7 \\
\hline ドナー年齢 & $10 \sim 15$ 歳 & $15 \sim 18$ 歳 & 6 歳未満 & $15 \sim 18$ 歳 & $10 \sim 15$ 歳 & $10 \sim 15$ 歳 \\
\hline 心臟 & $\begin{array}{c}10 \text { 代男児 } \\
\text { (237 日) }\end{array}$ & $\begin{array}{c}10 \text { 代男児 } \\
\text { (341 日) }\end{array}$ & $\begin{array}{c}<10 \text { 歳女児 } \\
\text { (267 日) }\end{array}$ & $\begin{array}{c}10 \text { 代女児 } \\
\text { (264 日) }\end{array}$ & $\begin{array}{c}10 \text { 代男児 } \\
\text { (865日) }\end{array}$ & $\begin{array}{c}10 \text { 代女児 } \\
\text { (871 日) }\end{array}$ \\
\hline 両肺 & 50 代女性 & 40 代女性 & & & 30 代女性 & \\
\hline 肝臓 & 20 代男性 & $\begin{array}{c}<10 \text { 歳女児 } \\
10 \text { 代女児 }\end{array}$ & < 10 歳女児 & 60 代男性 & 30 代女性 & 40 代男性 \\
\hline 膵腎同時 & 30 代女性 & 30 代女性 & & $\begin{array}{c}30 \text { 代女性 } \\
\text { 膵単独 }\end{array}$ & 40 代女性 & 40 代男性 \\
\hline 腎臓 & 60 代男性 & 60 代女性 & 60 代女性 (2 腎) & 40 代女性 & 50 代男性 & 40 代男性 \\
\hline 小腸 & & 30 代女性 & & & & \\
\hline
\end{tabular}

*心臓：（）内, 待機期間

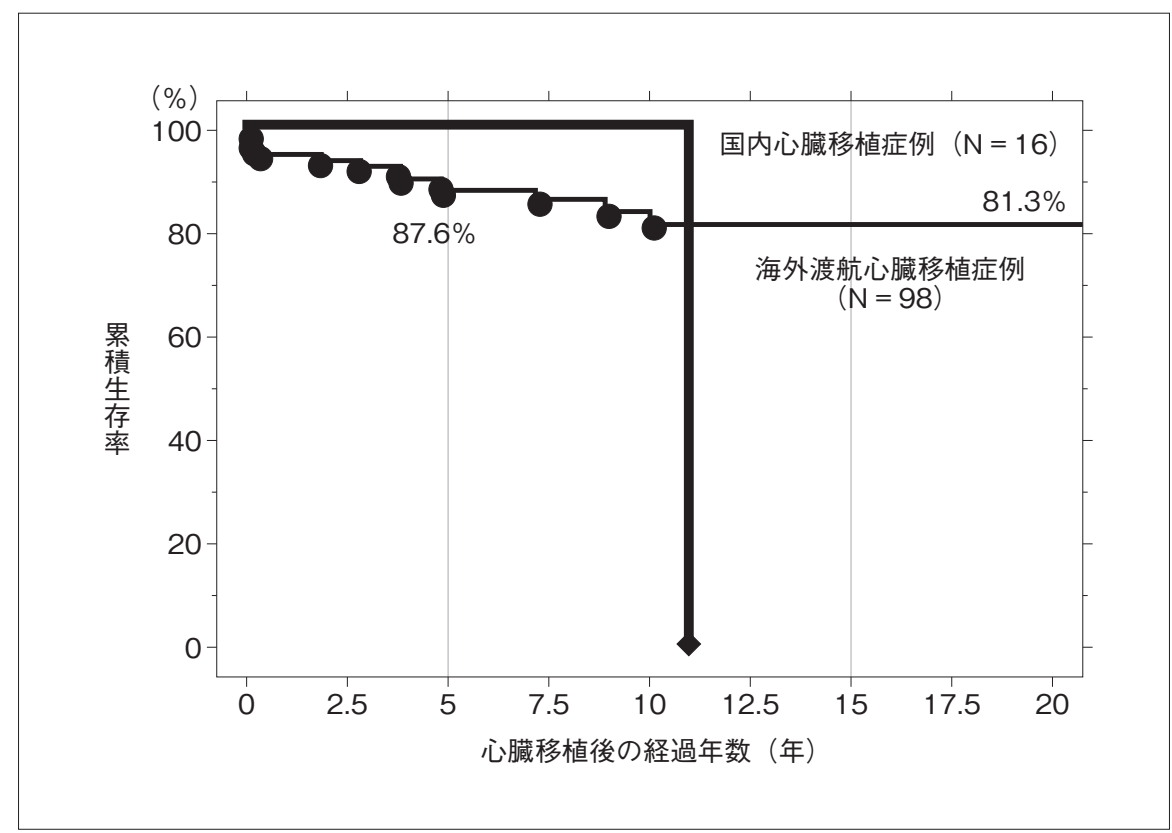

Fig. 6 日本人小児の心臓移植の累積生存率

【参考文献】

1) Dipchand A, Kirk R, Edwards LB, et al: The registry of the International Society for Heart and Lung Transplantation: Sixteenth official pediatric report-2013. J Heart Lung Transplant 2013; 32: 979-988

2)松下 享, 北 知子, 三輪谷隆史, ほか: 小児に対する国 内脳死後心臓移植の症例. 日小児循環器会誌 2001; 17: 738-743
3) 福嶌教偉, 宮本裕治, 大竹重彰, ほか: 小児末期的循環不 全に対する機械的循環補助並びに心臟移植. 日小児循環 器会誌 $2003 ;$ 19: 47-52

4) Ueno T, Fukushima N, Kogaki S, et al: First Pediatric Heart Transplantation From a Pediatric Donor Heart in Japan. Circ J 2012; 76: 752-754

5) Kantrowitz A, haller JD, Joos H, et al: Transplantation of the heart in an infant and an adult. Am J Cardiol 1968; 22: 782790 
6) Cooley DA, Frasier OH, van Buren CT, et al: Cardiac transplantation in an 8-month-old female infant with subendocardial fibroelastosis. JAMA 1986; 256: 1326-1329

7) Bailey LL, Concepcion W, Shattuck H, et al: Method of heart transplantation used for treatment of hypoplastic left heart syndrome. J Thorac Cardiovasc Surg 1986; 92: 1-5

8) 日本循環器学会: 小児期心疾患における薬物治療XIV 小 坚臓器移植の免疫抑制薬. 循環器病の診断と治療に関す るガイドライン2012: 234-243

9)Boucek MM, Mathis CM, Boucek RJ, et al : Prospective evaluation of echocardiography for primary rejection surveillance after infant heart transplantation: Comparison with endomyocardial biopsy. J Heart Lung Transplant 1994; 13: $66-73$

10) 小野安生, 福嶌教偉: 小児期拡張型心筋症の自然予後 心 臓移植対象例における検討. Annual Review循環器. 東京, 中外医学社 2008, pp297-301

11) 西川俊郎, 佐地 勉, 井埜利博, ほか: 関東心筋疾患研究 会 - 日本小児循環器学会移植委員会: 小児期心筋症の全 国調査結果. 日小児循環器会誌 2001; 16: 223-229

12) 福嶌教偉: 異種心臓移植の臨床と臨床応用を目指した霊 長類異種同所性心臓移植実験.松田暉監修, 布田伸一・福 嶌教偉編; 心臓移植. 東京, 丸善出版 2012, pp440-444

【小児循環器専門医のための総説シリーズ】

\begin{tabular}{|c|c|c|}
\hline \multicolumn{2}{|r|}{ 項立て } & \multirow[t]{2}{*}{ 掲載号 } \\
\hline 1 & 胎児循環生理 & \\
\hline 2 & 心血管系の身体所見 専門医に必要な循環器系理学所見のポイント & \\
\hline \multirow[t]{4}{*}{3} & 薬物について & \\
\hline & 3-1 利尿薬の使い方 & \\
\hline & 3-2 血管拡張剂について & \\
\hline & 3-3 その他 & \\
\hline 4 & 鎮痛・鎮静 & \\
\hline 5 & 肺高血圧の治療戦略 & \\
\hline 6 & 失神について & $30-4$ \\
\hline 7 & 呼吸と循環 & \\
\hline 8 & 超音波検査の原理から応用 & \\
\hline 9 & 心臟カテーテル検査によって得られた結果をどう解釈するか & \\
\hline 10 & 心臟 CT & \\
\hline 11 & 心臓 MRI & \\
\hline 12 & 心臓核医学 & $30-4$ \\
\hline 13 & 運動負荷試験について & \\
\hline \multirow{2}{*}{14} & 先天性心疾患の非手術歴(自然歴) 1 & $30-2$ \\
\hline & 先天性心疾患の非手術歴 (自然歴) 2 & $30-3$ \\
\hline 15 & チアノーゼについて & \\
\hline 16 & ペースメーカのすべて & \\
\hline 17 & 小児の心臓移植 & $30-4$ \\
\hline 18 & 体外循環 & \\
\hline 19 & 代表的な手術法 その工夫と問題点 & \\
\hline 20 & 先天性心疾患診療における死生学 & $30-3$ \\
\hline 21 & 小児循環器専門医に必要な統計学 & $30-2$ \\
\hline 22 & 臨床研究と倫理委員会と個人情報保護 & $30-4$ \\
\hline 23 & 川崎病 & \\
\hline 24 & カテーテル治療 & \\
\hline 25 & 不整脈治療 & \\
\hline 26 & 感染性心内膜炎 & \\
\hline 27 & 学校生活, 運動制限 & $30-1$ \\
\hline 28 & 心臟突然死 & \\
\hline
\end{tabular}

